\title{
Kuasi Kontrak Terhadap (Kitab Undang-Undang Hukum Perdata)
}

\author{
Oleh : Patawari 1 \\ NP. P0400311405
}

Istilah kuasi kontrak biasa juga disebut dengan kontrak tersamar (implied contract, quast contract). Kuasi kontrak dipahami sebagai perikatan yang timbul bukan karena perjanjian, tetapi karena di penuhinya syarat tertentu, sehingga telah ada kontrak $^{2}$.

Sedangan menurut Munir Fuadi adalah3 "Tidak semua kontrak dapat terlihat dengan jelas adanya kata sepakat. Namun, sampai batas- batas tertentu bahkan suatu kontrak dianggap sudah terbentuk, sungguh pun kesepakatan kehendak tidak jelasjelas kelihatan. Misalnya kesepakatan kehendak dalam jenis kontrak yang disebut dengan " kontrak tersamar" (implied contract, quast contract).

\section{Penjelasan}

Kuasi kontrak pada dasarnya diketemukan pada tradisi hukum eropa kontinental, maupun dalam tradisi hukum anglo saxon. Namun dalam "sistem hukum di Indonesia"4 terkhusus pada Kitab Undang-Undang Hukum Perdata tidak ditemukan adanya kuasi kontrak (quast contract), karena kuasi kontrak adalah masuk dalam kategori bukan/tidak bersahaja atau kontrak yang dapat dilaksanakan dengan mudah karena para pihak hanya terdiri atas masing- masing satu orang dan objek kontaknya pun hanya satu macam, dan lain- lain yang terkait dengan kontrak tersebut serba bersahaja.

Beberapa kontrak yang bukan atau tidak bersahaja menurut Ahmadi Miru ${ }^{5}$ yaitu:
a. Kontrak bersayarat
b. Kontrak dengan ketetapan waktu
c. Kontrak mana suku atau alternative
d. Kontrak tanggung rentang atau tanggaung menaggung

\footnotetext{
${ }^{1}$ Patawari 2012 Kuasi Kontrak Terhadap (Kitab Undang-Undang Hukum Perdata) Tugas Mk Sistem Hukum. Program Doktor Ilmu Hukum UNHAS.

${ }^{2}$ Di terangkan oleh Prof. DR. Nurhayati Abbas, SH.MH perkuliahan sistem hukum program doktoral ilmu hukum unhas pada 21 Desember 2011

${ }^{3}$ Munir Fuady, Hukum Kontrak (Dari sudut pandang Hukum Bisnis) (Bandung: Citra Aditrya Bakti,20001) hal $50-52$

${ }^{4}$ Sistem hukum indonesia sebagian kalangan menganggap hukum campuran, anglo saxon, civil law, hukum Islam ditandai dengana danya KHI (kompilasi Hukum Islam), hukum adat. dan juga sebagaian kalangan menganggap sebagai sistem hukum campuran.

5 Ahmadi Miru, Hukum Kontrak Perancangan Kontrak,( Jakarta,Raja Grafindo Persada,2008) hal 52-61
} 
e. Kontrak yang dapat di bagi dan tidak dapat dibagi

f. Kontrak dengan ancaman hukuman

g. Kuasi kontrak

Dari beberapa ulasan tersebut di atas, membenarkan bahwa dalam Burgerlijk Wetboek (BW) adalah memang tidak adanya kuasi kontrak yang tercantum dalam pasal-pasal. Hal ini dapat di benarkan oleh karena di dalam BW memang memberikan patokan syarat di dalam berkontrak sebagaimana termaktub dalam Pasal 1320 KUHPerdata $^{6}$, antara lain sebagai berikut:

1. Sepakat mereka yang mengikatkan dirinya;

2. Kecakapan untuk membuat suatu perikatan;

3. Suatu hal tertentu;

4. Suatu sebab yang halal.

Sehingga di dalam berkontrak adalah harus terpenuhi 4 unsur tersebut, sedangkan pada kuasi kontrak adalah tidak memenuhi unsur sebagaimana pada ayat 1 .

pembenaran penulis bahwa kuasi kontrak adalah tidak di temukan di dalam BW adalah merupakan pandangan yang berdasar pada kebenaran asas legalitas, dimana tidak dapat di hukum oleh karena tidak adanya dasar hukum yang mengikat.

\section{Penjelasan Sisi lain}

Di dalam penjelasan sub di atas menegaskan bahwa pada sudut pandang legalitas memang dibenarkan tidak adanya dasar hukum kuasi kontrak di dalam BW dikarenakan adanya syarat yang tidak terpenuhi.

Sisi lain, pada pendekatan sosiologis dan pendekatan filosofis tentu akan memberikan penjelasan tersendiri mengenai kuasi kontrak, di mana kuasi kontrak bermuara pada adanya keputusan Hakim maka hakim tidak serta merta melihat suatu obyek perkara dengan ansich melihat pada sudut pandang normatif. Akan tetapi, juga harus melihat pada sudut pandang sosialogis dan filoofis.

Pada pandangan sosiologis, dicontohkan suatu masyarakat di mana terjadi musibah dan atau kecelakaan dan membutuhkan perwatan dari dokter, maka tentu tidak selalu harus berdasarkan pada adanya kontrak (sepakat mereka mengikatkan dirinya)antara dokter dan pasien. Sebab memang para pasien membutuhkan perawatan dan dokter adalah berfungsi sebagai perawat (mengobati pasien). Maka hakim harus

\footnotetext{
${ }^{6}$ KUHperdata
} 
melihat tatkala pasien sembuh, ketika terjadi tuntutan untuk ganti rugi perawatan adalah tidak perlu dikabulkan.

Sedangkan pada pendekatan filosofis, adalah tidak semua orang yang membutuhkan perawatan itu di kabulkan. akan tetapi, Hakim harus melihat bagaimana klas sosial dari pada pasien yang akan di rawat. Ketika pasien tersebut memang berasal dari pada masyarakat yang tidak mampu, maka tentukah harus dirawat tanpa adanya tuntutan untuk mebayar biaya perawatan. Akan tetapi, jika mereka yang berasal dari mayarakat yang mampu, maka hakim tentu mempunyai pertimbangan lain yang adil. ${ }^{7}$

\section{Kesimpulan}

Dari beberapa ulasan di atas penulis mencoba menyimpulakan bahwa:

a. dalam kitab Udang-undang Hukum perdata secara normatif tidak ditemukan di dalam pasal-pasal. Karena tidak memenuhi unsur perjanjian sebagaimana yang ditegasnkan di dalam Pasal 1320 KHUperdata

b. dalam perkara yang terkait dengan kuasi kontrak, maka pendekatan, sosiologis dan filosofis adalah menjadi pegangan Hakim di dalam suatu putusan demi untuk mencapai suatu keseimbangan hukum dan mayarakat.

\footnotetext{
7 adil dalam konteks ini adalah seorang hakim tidak selamnya harus memutuskan perkara dengan menyamakan antara pasien yang lemah (kurang mampu) dan masyarakat yang Kuat (mampu). Sebab tujuan hakim adalah menetapkan perkara untuk mendapatkan keadilan, itulah sehingga asa equality before the law adalah tidak selalu mencapai dan atau menemukan keadilan yang sesunggunhya. Maka penulis menganggap dengan demikian tujuan hukum itu tidak berada pada keadilan, pepastian, dan ketaatan akan tetapi tujuan hukum itu adalah keseimbangan. Dan menjadi tugas penting para hakim untuk mencapai keseimbangan yang dimaksud.
} 